\title{
Etyka międzynarodowa a odpowiedzialność za ochronę
}

\section{Streszczenie}

Celem artykułu jest przybliżenie nowej, kształtującej się od początku XXI w. instytucji prawa międzynarodowego, jaką stanowi odpowiedzialność za ochronę (responsibility to protect). Instytucja odpowiedzialności za ochronę interpretowana jest w świetle teorii stosunków międzynarodowych oraz etyki międzynarodowej. W artykule zastosowano analityczno-deskryptywną metodę badawczą. Stosunkowo nowa instytucja odpowiedzialności za ochronę zyskała ze względu na swoje znaczenie powszechną akceptację społeczności międzynarodowej, aczkolwiek spotkała się też z krytyką jako zbyt trudna do zastosowania. Zasługuje jednak na uwagę jako najbardziej radykalny program legitymizujący działania podejmowane pod auspicjami Narodów Zjednoczonych mające na celu ochronę ludności cywilnej w sytuacjach zagrożenia.

Słowa kluczowe: etyka, odpowiedzialność, realizm, liberalizm, neomarksizm, szkoła angielska.

Klasyfikacja JEL: F51, K33.

\section{Wprowadzenie}

Koncepcja odpowiedzialności za ochronę (responsibility to protect - R2P) zyskała powszechną akceptację społeczności międzynarodowej, chociaż spotkała się też z krytyką jako idea zbyt trudna do przełożenia na działanie. Niemniej jednak stanowi jak dotąd najbardziej radykalny program legitymizujący działania

Danuta Kabat-Rudnicka, Uniwersytet Ekonomiczny w Krakowie, Wydział Ekonomii i Stosunków Międzynarodowych, Katedra Polityki Ekonomicznej i Programowania Rozwoju, ul. Rakowicka 27, 31-510 Kraków, e-mail: kabatd@uek.krakow.pl 
podejmowane pod auspicjami Narodów Zjednoczonych (NZ) mające na celu ochronę ludności w sytuacjach zagrożenia. R2P posiada mocne zakorzenienie w moralności i dlatego stanowi przedmiot zainteresowania etyki międzynarodowej. Pomimo wielu niedoskonałości R2P jest podstawą i inspiracją działań w licznych konfliktach, przy czym działania te, takie jak np. interwencja humanitarna, mające mocne podstawy moralne, nierzadko budzą wątpliwości natury prawnej ${ }^{1}$.

Koncepcja R2P została przygotowana przez F. Denga i R. Cohena, a następnie rozwinięta przez sekretarza generalnego Narodów Zjednoczonych K. Annana. R2P tworzy nową perspektywę, zmieniając argumentację w duchu tradycyjnej suwerenności na międzynarodową odpowiedzialność, a zarazem nową narrację rozwijającą ideę, że społeczność międzynarodowa ma obowiązek zapewnienia poszanowania praw człowieka i standardów humanitarnych [Knight 2011, s. 20]. Twórcy koncepcji należą do zdeklarowanych zwolenników i obrońców praw człowieka. Wychodzą z założenia, że suwerenność i ochrona jednostek nie wykluczają się nawzajem, co więcej, stoją na stanowisku, że suwerenność nie jest absolutna, lecz warunkowa, co z kolei oznacza, że rząd jest odpowiedzialny nie tylko za ludność zamieszkującą w granicach suwerennego państwa, lecz także wobec wspólnoty tworzonej przez suwerenne państwa [Knight 2011, s. 20-21].

$\mathrm{R} 2 \mathrm{P}$ jest osadzone w tradycji prawa międzynarodowego humanitarnego i nie narusza ducha i litery Karty NZ - konstytucji wspólnoty międzynarodowej. Stąd też uciekanie się do rozwiązań siłowych jest zastrzeżone dla sytuacji wyjątkowych i traktowane jako ostateczność przy zachowaniu kryteriów uzasadniających użycie siły i warunków decydujących o sposobie przeprowadzenia interwencji. Istotne jest tutaj to, że odpowiedzialność za ochronę życia i dobra obywateli spoczywa w pierwszym rzędzie na suwerennym państwie, w dalszej kolejności na organach krajowych działających we współpracy z podmiotami zewnętrznymi, a na koniec na organizacjach międzynarodowych.

Kryteria uzasadniające rozwiązania siłowe, do których należą: właściwa władza, uzasadniona przyczyna, właściwy zamiar, ostateczność i proporcjonalność zastosowanych środków, skalkulowane szanse na uwieńczone powodzeniem działanie [The Responsibility... 2001, s. 32], są przedmiotem szerokiej dyskusji, a sama koncepcja R2P pozostaje nadal swoistym novum, czego dowodzi m.in. ostrożność, z jaką podchodzą do niej rządy i organizacje międzyrządowe. Za znamienny uznać należy fakt, że jak dotąd jedynie Unia Afrykańska wprowadziła R2P do swego statutu. Zgodnie z nim ma ona prawo do interweniowania

1 W literaturze przedmiotu zwraca się uwagę na to, że termin „interwencja humanitarna” może być potraktowany jako oksymoron, ponieważ humanitarna może być pomoc, a nie interwencja. Z kolei interwencja jest przymusowa i zbrojna, w rezultacie zaś jest wojną [Zajadło 2009, s. 282]. 
w sprawy wewnętrzne państw - członków, w sytuacji gdy ludności tych państw grozi niebezpieczeństwo, że mogą stać się ofiarami zbrodni wojennych, zbrodni przeciwko ludzkości czy zbrodni ludobójstwa ${ }^{2}$.

Należy też zaznaczyć, że R2P jest w większej mierze koncepcją polityczną niż prawną, nie ma bowiem stosownych konwencji międzynarodowych. Stąd też może być co najwyżej uważana za normę międzynarodowego prawa zwyczajowego [Max Planck... 2010, VanLandingham 2012, s. 63-85]. Wynikające z niej zobowiązanie państw do ochrony własnej ludności przed zbrodniami ludobójstwa, zbrodniami wojennymi, czystkami etnicznymi oraz zbrodniami przeciwko ludzkości zostało zaakceptowane przez społeczność międzynarodową i sprawia, że R2P, jakkolwiek nie jest uznane de iure, de facto zyskało szeroką aprobatę. Za uznaniem R2P jako normy międzynarodowego prawa zwyczajowego przemawia również dotychczasowa praktyka i opinio iuris. Propagowany jest także pogląd, że R2P jest miękkim prawem (soft law), nie jest bowiem sprawą oczywistą, jakie zobowiązania nakłada na społeczność międzynarodową oraz na których aktorach głównie spoczywa zobowiązanie [Reinold 2013, s. 92-93].

Celem artykułu jest przybliżenie nowej instytucji prawa międzynarodowego, jaką jest odpowiedzialność za ochronę. Instytucja ta zostanie scharakteryzowana w odniesieniu do teorii stosunków międzynarodowych oraz etyki międzynarodowej przy zastosowaniu analityczno-deskryptywnej metody badawczej.

\section{Teoretyczne ujęcia stosunków międzynarodowych a etyka międzynarodowa}

Informacji na temat charakteru zobowiązań aktorów międzynarodowych dostarcza teoria stosunków międzynarodowych. W trzech najczęściej przywoływanych nurtach teoretycznych, tj. realistycznym, liberalnym i neomarksistowskim, założenia odnośnie do roli aktorów w polityce międzynarodowej, interesów, jakimi się kierują, wartości, jakie wyznają, otoczenia, w jakim funkcjonują, oraz zdolności, jakimi dysponują, różnią się wyraźnie. Co więcej, każda z orientacji teoretycznych dostarcza uzasadnienia zarówno dla interwencji, jak i dla nieinterwencji militarnej, chociaż każda z nieco innych powodów.

Szkoła realistyczna postrzega interesy państw jako istotny wyznacznik polityki, a system międzynarodowy jako stan wojny, w którym bezpieczeństwo

2 Art. 4 (h) Constitutive Act of the African Union [2000], który wszedł w życie 26 maja 2001 r. Termin „ludobójstwo” (genocide) został ukuty przez R. Lemkina, polskiego prawnika pochodzenia żydowskiego, natomiast pojawił się po raz pierwszy w jego książce opublikowanej w 1944 r. pt. Axis Rule in Occupied Europe („Rządy państw Osi w okupowanej Europie”). Więcej nt. polskiego wkładu w rozwój koncepcji R2P zob. [Kuźniar 2015, s. 47-61]. 
państw jest względne. Co więcej, jest ono potencjalnie zagrożone, stąd jego priorytetowy charakter. Kluczowe jest pytanie, czy interweniować, czy też nie, chociaż nie jest stawiane wprost w podstawowych pracach szkoły realizmu, np. Politics among Nations H.J. Morgenthau czy America's Strategy in World Politics: The United States and the Balance of Power N.J. Spykmana [Halpern 1964, Smith 1989, s. 1-26]. Z prac realistów wynika, że państwa winny interweniować wówczas, gdy leży to w ich interesie, a nie interweniować, jeśli tak nie jest, w obu przypadkach podstawą decyzji nie powinny być jednak względy odnoszące się do prawa międzynarodowego czy etyki [Doyle 2011, s. 74]. Istota realizmu została jasno przedstawiona przez Tukidydesa w księdze piątej Wojny Peloponeskiej (Dialog melijski), gdzie czytamy ,(...) sprawiedliwość w ludzkich stosunkach jest tylko wtedy momentem rozstrzygającym, jeśli po obu stronach równe siły mogą ją zagwarantować; jeśli zaś idzie o możliwości, to silniejsi osiągają swe cele, a słabsi ustępują" [Tukidydes 2003, s. 310].

Rozpatrywanie stosunków międzynarodowych w kategoriach etycznych sprowadzane było do wymiaru marginalnego lub neutralizowane w imię naukowego obiektywizmu, który zdawały się oferować założenia realistów. Zakładanie przez realistów, że państwa niezmiennie kierują się interesem narodowym, pomocne było w ignorowaniu skomplikowanego etycznie wymiaru stosunków międzynarodowych. Pozbawiony dylematów etycznych obraz aktora w polityce międzynarodowej zawdzięczali realiści przyjmowanej postawie strategicznej, szczególnej kalkulacji naukowej, zgodnie z którą system międzynarodowy jest stabilny, jeśli państwa utrzymują równowagę sił, realizując zarazem interesy narodowe. Nic więc dziwnego, że dyskusja na temat miejsca i roli etyki w stosunkach międzynarodowych - dyscyplinie zdominowanej przez powyższe założenia - stanowiła wyzwanie dla realizmu [Hutchings 2001, s. 1-2]. Od początków wyodrębnienia się stosunków międzynarodowych jako dyscypliny akademickiej zarysowała się ogólna tendencja do etykietowania rozważań i sporów moralnych jako przejawu naiwnego idealizmu na równi z mitem, że „poważna” naukowa analiza spraw międzynarodowych nie może dotyczyć kwestii etycznych [Hutchings 2001, s. 2].

Z kolei neomarksizm postrzega politykę międzynarodową, w szczególności zaś prawo międzynarodowe, jako odzwierciedlenie interesów klasowych, które tak naprawdę rządzą społecznością międzynarodową. Zdaniem przedstawicieli tej szkoły społeczność międzynarodowa przypomina międzynarodową wojnę domową, w której kapitaliści występują przeciwko robotnikom tak w kraju, jak i za granicą, a granice państwowe są fikcją, nie odzwierciedlają bowiem rzeczywistych podziałów w polityce światowej. Niemniej jednak granice narodowe mogą odgrywać (i odgrywały) postępową rolę w historii. Jednakże ze względu na to, że „socjalistyczne krucjaty” oznaczały ogromne cierpienie i niestabilność, socjaliści drugiej międzynarodówki, marksiści przed 1914 r. i socjaldemokraci po 1914 r. 
często bronili zasady nieinterwencji, wyjąwszy sytuacje, gdy postrzegali wojnę jako wyraźnie przyśpieszającą postępowe zmiany lub powstrzymującą siły reakcyjne [Doyle 2011, s. 75].

Szkoła liberalna najbardziej angażuje się w sprawy etyki zarówno nieinterwencji, jak i interwencji. Podobnie jak poprzednie nurty w teorii stosunków międzynarodowych odwołuje się do nacjonalizmu, a konkretnie do zasady samostanowienia narodów, która winna być - zdaniem jej przedstawicieli - równoważona przez powszechne prawa człowieka i bezpieczeństwo narodowe. Nieingerencja in genere, a nieinterwencja in specie, była i jest nadal szczególnie ważną zasadą dla liberalnych polityków i moralistów. $Z$ jednej strony liberałowie dostarczają poważnych argumentów na rzecz rygorystycznego przestrzegania zasady nieinterwencji, podkreślając, że tylko wewnątrz bezpiecznych granic ludzie mogą rządzić się jako wolni obywatele, z drugiej zaś zasada godności ludzkiej uzasadnia odrzucenie i zignorowanie zasady nieinterwencji [Doyle 2011, s. 75-76]. Natomiast koronnym argumentem jest to, że nieinterwencja stanowi wyraz poszanowania innych i chroni godność ludzką, pozwalając obywatelom na wybór określonego sposobu życia bez jakiejkolwiek ingerencji z zewnątrz; jeśli bowiem prawa demokratyczne i wolności liberalne mają mieć znaczenie, to winny być wypracowane przez tych, którzy je uznają i urzeczywistniają [Doyle 2011, s. 76].

Zdaniem liberałów, zwłaszcza tych czerpiących z myśli J.S. Milla, interwencja podważa autentyczność wewnętrznej walki o władzę, ponieważ rząd przejęty w drodze interwencji nie byłby autentyczny ani też samostanowiący, lecz zdeterminowany przez innych; nie byłby więc rządem, jaki ustanowili obywatele. J.S. Mill nie uważałby też za właściwe „eksportowanie” wolności. Tylko dzięki zdobywaniu i utrzymywaniu wolności własnymi siłami (przez lokalne starania) można poznać jej prawdziwą wartość, ponieważ tylko w ten sposób nabywa się politycznych zdolności, by właściwie bronić jej przed zagrożeniami zarówno wewnętrznymi, jak i zewnętrznymi [Doyle 2011, s. 76; Mill 1859]. Istnieją jednak argumenty przemawiające za niestosowaniem się do zakazu interwencji, np. w sytuacji gdy wojna domowa przedłuża się, gdy żadna ze stron nie jest wystarczająco silna, a cierpienia ludności niezaangażowanej bezpośrednio w walce stawiają pod znakiem zapytania celowość rozstrzygnięcia opartego na siłach lokalnych. Niekiedy też samostanowienie, któremu ma służyć nieinterwencja, jest tak dalece wątpliwe - podważają je wewnętrzny ucisk i cierpienie, że nieinterwencja petryfikuje jedynie układ wewnętrzny. W okolicznościach takich jak kontrinterwencja podjęta w wyniku wcześniejszej interwencji lub wspieranie secesjonistów należących do podporządkowanej lub słabszej społeczności zdominowanej przez większą rząd traci legitymację do bycia tym jedynym i prawdziwym [Doyle 2011, s. 76-77; Mill 1859]. W takich szczególnych okolicznościach nawet rzecznicy liberalnego komunitaryzmu (communitarian liberals) twierdzą, że można interweniować dla 
celów humanitarnych, by powstrzymać naruszanie prawa ludności do przetrwania. Kiedy jesteśmy świadkami masakry, ludobójstwa czy zinstytucjonalizowanego niewolnictwa, mamy powody, by kwestionować istnienie związku pomiędzy uciemiężoną ludnością a państwem. W takich okolicznościach interwencja może przynieść rozwiązanie i jest usprawiedliwiona, przy czym interweniujący winien wykazać się moralnie dającym się obronić motywem i mieć na celu zakończenie rzezi oraz ustanowienie samostanowiącego narodu. Interweniujący winien działać jako ostateczny arbiter po wyczerpaniu możliwości pokojowego rozstrzygnięcia i tylko wówczas, gdy jest oczywiste, że może uratować więcej istnień ludzkich, niż pochłonie ofiar sama interwencja, co więcej, winien działać, używając minimum koniecznej siły [Doyle 2011, s. 77]. Z kolei zwolennicy kosmopolitycznego liberalizmu (cosmopolitan liberals), zwłaszcza ci uznawani za zagorzałych kosmopolitów, utrzymują, że prawa wynikające z kosmopolitycznego pojmowania wolności mają walor uniwersalny. Jakakolwiek próba ich naruszenia winna spotkać się ze stanowczym sprzeciwem, jednakże pod warunkiem że da się to tak uczynić, aby nie spowodować większych szkód niż te, którym chcemy zapobiec. Kosmopolici są sceptyczni co do zasady nieinterwencji, uważają ją za wtórną lub instrumentalną, możliwą do zastosowania wszędzie tam, gdzie wydaje się ona chronić zasady, które uważane są za bardziej fundamentalne w sensie etycznym. Zarówno kosmopolici, jak i komunitarianie opowiadają się jednak za zasadą ostateczności i proporcjonalności, dlatego w praktyce kosmopolici bardziej zorientowani na interwencję będą popierać interwencję jedynie w skrajnych sytuacjach, w których komunitarianie byliby także skłonni odrzucić lub zignorować wspólnotę narodową [Doyle 2011, s. 77].

Zasadniczo mamy do czynienia z trzema tradycjami myślenia w kategoriach etycznych ściśle korespondującymi z gospodarczą, społeczną i polityczną stroną liberalizmu. Należy wymienić: liberalny kontraktarianizm (liberal contractarianism), który wywodzi prawa państw z praw naturalnych jednostek i postrzega państwo jako dobrowolne umowne stowarzyszenie (voluntary contractual association); tradycję kantowską, przyjmującą postać chrześcijańskiego paradygmatu prawa naturalnego, dowodzącą istnienia uniwersalnych, transcendentnych praw moralnych, pierwotnych i mających pierwszeństwo przed wszelkim innym uzasadnieniem władzy politycznej oraz przypisującą wyjątkowy status moralny jednostce z uwagi na jej zdolność poznania i ustanawiania prawa moralnego; tradycję utylitarną, która utrzymuje, że podstawowe fakty na temat kondycji i motywacji ludzkiej podtrzymują sądy moralne [Hutchings 2001, s. 30-31]. Zarówno liberałowie kierujący się inspiracją kantowską, jak i zwolennicy utylitaryzmu mają tendencję do powoływania się na uniwersalne zasady, po to by legalizować sądy moralne i nakazy w kontekście międzynarodowym. Co więcej, postrzegają sprawy międzynarodowe jako obszar, w którym winny obowiązywać zasady etyczne. Z kolei libe- 
ralny kontraktarianizm, mimo że opiera się na idei uniwersalnych praw jednostek, akceptuje ideę władzy państwa zgodnie z kontraktualistyczną fikcją wyrażającą się w tendencji do przypisywania państwu więcej właściwości etycznych niż w kantyzmie czy utylitaryzmie. Dodać należy, że w ostatnich latach umocniła się tradycja realistyczna przez zwrot w kierunku komunitaryzmu (communitarian turn), który umieszcza zasadność osądu moralnego nie w państwie jako prawnej jednostce z suwerenną władzą, lecz w państwie narodowym jako wyrazicielu szczególnej kultury czy szczególnego sposobu życia [Hutchings 2001, s. 31].

W głównym nurcie współczesnej teorii etycznej ponawiane są pytania dotyczące sprawiedliwości w konfliktach zbrojnych, praw człowieka, praw narodów do samostanowienia i globalnej sprawiedliwości dystrybutywnej, w odniesieniu do których stanowiska kantowskie, utylitarne, kontraktualne i komunitarne konkurują ze sobą w udzielaniu odpowiedzi na pytanie, co jest właściwe, a co nie jest [Hutchings 2001, s. 31]. W przypadku kantyzmu, utylitaryzmu i kontraktualizmu pierwszeństwo - w sensie etycznym - należy się jednostce i jest rozumiane w kategoriach szczególnego modelu autonomii (naturalna, negatywna wolność kontraktualizm, racjonalna, pozytywna wolność - kantyzm) lub motywacji oraz osądowi normatywnemu podbudowanemu idealistyczną ontologią, natomiast w przypadku komunitaryzmu pierwszeństwo przypisuje się narodowi dokonującemu aktu samookreślenia oraz normatywnemu osądowi podbudowanemu idealistyczną ontologią [Hutchings 2001, s. 32].

Nie sposób pominąć szkoły angielskiej (społeczności międzynarodowej), której przedstawiciele uważają, z jednej strony, że kluczowymi aktorami w stosunkach międzynarodowych są państwa działające we własnym, dobrze pojętym interesie, które muszą polegać na sile, po to by utrzymać należne im miejsce na arenie międzynarodowej, z drugiej natomiast - państwa zorientowane na swój interes, które zdołały utworzyć społeczność międzynarodową, w ramach której uznają pewne ograniczenia moralne, co sprawia, że podejście to jest $\mathrm{w}$ równej mierze realistyczne i idealistyczne [Frost 2013, s. 65].

Przedstawiciele szkoły angielskiej odwołują się do pozytywizmu prawniczego, podkreślając suwerenną wolę państw, pluralizm i uznając, że prawo winno być oddzielone od moralności, oraz do prawa naturalnego, kładąc nacisk na godność ludzką, solidaryzm oraz ścisły związek pomiędzy prawem a moralnością. $\mathrm{W}$ prawie międzynarodowym opartym na pozytywizmie prawniczym nie ma miejsca na interwencję humanitarną z wyjątkiem tej odwołującej się do zgody państw lub decyzji Rady Bezpieczeństwa (RB). Z kolei w podejściu opartym na prawie naturalnym prawo międzynarodowe winno być tworzone w celu ochrony godności ludzkiej jako podstawowej wartości społeczności międzynarodowej, stąd - zdaniem solidarystów - jest miejsce dla interwencji humanitarnej [Baaz 2013, s. 134-135; Zajadło 2005, s. 56-57]. 


\section{Odpowiedzialność za ochronę}

Koncepcja R2P została wprowadzona do słownika prawa międzynarodowego w 2001 r. i opiera się na dwóch założeniach, które łączy i operacjonalizuje. Po pierwsze, suwerenność państwa implikuje odpowiedzialność, przy czym pierwotna odpowiedzialność za ochronę ludności spoczywa na samym państwie. Po drugie, wszędzie tam, gdzie ludność doznaje poważnej krzywdy w wyniku wojny domowej, powstania, represji lub upadku państwa, a państwo nie chce albo też nie jest w stanie jej powstrzymać lub zapobiec, zasada nieinterwencji ustępuje przed R2P [The Responsibility... 2001, s. xi].

Koncepcja R2P została rozwinięta przez Międzynarodową Komisję ds. Interwencji i Suwerenności Państwa (International Commission on Intervention and State Sovereignty - ICISS), ustanowioną przez L. Axworthy'ego (Kanada) 14 września 2000 r., której współprzewodniczącymi byli G. Evans (Australia) i M. Sahnoun (Algieria) [Max Planck... 2010]. ICISS opracowała kryteria pozwalające na interwencję militarną w celu ochrony ludności, do których należą [The Responsibility... 2001, s. xii-xiii]:

1) sprawiedliwa przyczyna - ponieważ interwencja wojskowa mająca na celu ochronę ludności jest środkiem szczególnym i wyjątkowym, musi zaistnieć poważna i nieodwracalna szkoda dla ludzi lub prawdopodobieństwo, że taka szkoda pojawi się niezwłocznie; szkoda taka to utrata życia na większą skalę lub czystki etniczne na znaczną skalę;

2) zastosowanie zasad ostrożności, takich jak: właściwa intencja (podstawowym celem interwencji winno być powstrzymanie ludzkiego cierpienia lub zapobieganie mu), środek ostateczny (interwencja militarna może być uzasadniona tylko wówczas, jeśli wszystkie niemilitarne możliwości zapobiegania kryzysowi lub jego pokojowego rozwiązania zostały wzięte pod uwagę), środki proporcjonalne (skala, czas trwania oraz intensywność planowanej interwencji militarnej winny stanowić konieczne minimum), uzasadnione szanse (rozsądnie skalkulowana szansa na powodzenie przedsięwzięcia, tj. powstrzymania cierpienia lub zapobieżenia mu, które uzasadnia interwencję);

3) właściwa władza (najbardziej odpowiednim organem upoważniającym do podjęcia interwencji pozostaje RB);

4) zasady operacyjne: jasne cele, jedność dowodzenia, ochrona ludności jako podstawowy cel, zasady zaangażowania (precyzja, respektowanie zasady proporcjonalności, stosowanie się do zasad międzynarodowego prawa humanitarnego) oraz koordynacja działań z organizacjami humanitarnymi.

Należy odnotować, że ICISS celowo zmieniła narrację w debacie odnoszącej się do humanitarnej interwencji - prawo do interwencji zostało zastąpione prawem do ochrony, a koncentrując się na ochronie, a nie na interwencji, podkreśla znaczenie 
działań prewencyjnych [Rose 2014, s. 222]. Mamy więc wyraźne przesunięcie akcentów w debacie dotyczącej bezpieczeństwa ludności z suwerenności (interwencji) na odpowiedzialność za ochronę, co kładzie kres bezkarności państwa, gdy chodzi o jego obywateli oraz inną ludność zamieszkującą na jego terytorium. Jeśli państwo nie jest w stanie skutecznie chronić własnych obywateli lub innych osób zamieszkujących na jego terytorium, społeczność międzynarodowa winna wziąć na siebie odpowiedzialność za ochronę ludności bez względu na obywatelstwo. Innymi słowy, zamiast odwoływać się do struktur państwowych (państwo jako podmiot stosunków międzynarodowych) ICISS zaczyna kierować się ku przedmiotowi odpowiedzialności państwa, tj. obywatelom i wszystkim innym osobom znajdującym się w granicach suwerennego państwa [Warner 2013, s. 24-25].

ICISS wskazała także trzy szczególne rodzaje odpowiedzialności w ramach R2P: 1) odpowiedzialność za zapobieganie, która sprowadza się do identyfikowania przyczyn zarówno pierwotnych, jak i bezpośrednich w wewnętrznych konfliktach oraz innych kryzysach wywołanych przez człowieka; 2) odpowiedzialność za reagowanie, która polega na odpowiadaniu na podstawowe potrzeby przy zastosowaniu odpowiednich środków, w tym także środków przymusu, takich jak sankcje i międzynarodowe ściganie, a w sytuacjach skrajnych interwencje militarne; 3) odpowiedzialność za odbudowę, tj. pomoc przy odbudowie i pojednaniu, zwłaszcza po interwencji militarnej [The Responsibility... 2001, s. xi].

$\mathrm{Na}$ odnotowanie zasługuje również raport będący efektem panelu zainicjowanego przez ówczesnego sekretarza generalnego Narodów Zjednoczonych K. Annana w następstwie wojny iracko-amerykańskiej. W raporcie potwierdzona została nowa norma, która stanowi, że istnieje zbiorowa odpowiedzialność międzynarodowa za ochronę, egzekwowana przez RB, upoważniająca do militarnej interwencji jako środka ostatecznego w sytuacji ludobójstwa lub innego zabijania na większą skalę, czystek etnicznych lub poważnych naruszeń międzynarodowego prawa humanitarnego, w sytuacji gdy suwerenne rządy okazały się bezsilne lub też niechętne do podjęcia kroków mających zapobiec takim sytuacjom [A More Secure World... 2004, s. 57]. W raporcie wymieniono również pięć kryteriów (wcześniej rozwiniętych przez ICISS), które winny zawsze mieć zastosowanie w celu ustalenia, czy interwencja jest uzasadniona. Innymi słowy, rozważając, czy należy zezwolić na użycie siły militarnej, RB winna zawsze brać pod uwagę: 1) powagę zagrożenia (czy zagrożenie dla bezpieczeństwa państwa lub ludności jest wystarczająco oczywiste i poważne, by uzasadnić użycie siły militarnej, a w przypadku zagrożeń wewnętrznych, czy dotyczy ludobójstwa lub innych zbrodni na znaczną skalę, czystek etnicznych lub poważnych naruszeń międzynarodowego prawa humanitarnego, realnych lub wysoce prawdopodobnych); 2) właściwy cel (zasadniczym celem działań winno być powstrzymanie zagrożenia lub zapobieżenie mu); 3) ostateczny środek (zastosowany po rozwa- 
żeniu wszystkich innych niemilitarnych możliwości zapobieżenia zagrożeniu); 4) środki proporcjonalne (skala, czas trwania oraz intensywność działań militarnych winny stanowić konieczne minimum); 5) bilans skutków (istnienie uzasadnionej szansy na to, że działania militarne zakończą się powodzeniem, z konsekwencjami działania nie gorszymi niż konsekwencje bezczynności) [A More Secure World... 2004, s. 57-58].

Warto również wspomnieć o szczycie NZ w Nowym Jorku w 2005 r. zwołanym w 60. rocznicę powstania tej organizacji, na którym jednomyślnie przyjęto zasadę odpowiedzialności za ochronę - zdaniem niektórych stanowiącą jedno z największych osiągnięć w procesie reformowania NZ [Symonides 2006, s. 526]. W dokumencie końcowym stwierdza się, że każde państwo jest odpowiedzialne za ochronę mieszkańców przed ludobójstwem, zbrodniami wojennymi, czystkami etnicznymi oraz zbrodniami przeciwko ludzkości [2005 World Summit Outcome... 2005, s. 30, pkt 138]. Zgromadzenie Ogólne (ZO) potwierdziło ponadto możliwość (realność) podjęcia działań w sytuacji, gdy państwo nie wywiązuje się z obowiązku ochrony oraz konieczność przyjęcia rezolucji przez RB w celu sankcjonowania takich działań. Dokument stanowi, że w sytuacji gdy środki pokojowe okażą się niewystarczające, a władze krajowe jednoznacznie nie będą zdolne do ochrony własnej ludności przed ludobójstwem, zbrodniami wojennymi, czystkami etnicznymi oraz zbrodniami przeciwko ludzkości, społeczność międzynarodowa wyraża gotowość podjęcia akcji zbiorowej, przeprowadzonej w odpowiednim czasie i w sposób zdecydowany, w ramach RB oraz w zgodzie z postanowieniami Karty Narodów Zjednoczonych [1945], włączając postanowienia rozdziału VII, na podstawie indywidualnej oceny każdego przypadku i we współpracy z odpowiednimi organizacjami regionalnymi. ZO wyraziło również gotowość, jeśli będzie to właściwe i konieczne, do udzielenia państwom wsparcia w budowie ich zdolności do ochrony własnej ludności przed ludobójstwem, zbrodniami wojennymi, czystkami etnicznymi oraz zbrodniami przeciwko ludzkości, a także do pomocy ludności uciskanej jeszcze przed wybuchem kryzysu lub konfliktu [Heinze i Steele 2013, s. 147; Hehir 2013, s. 35; 2005 World Summit Outcome... 2005, s. 30, pkt 139]3.

${ }^{3}$ Koncepcja R2P opracowana przez ICISS znacząco różni się od tej przyjętej na szczycie w 2005 r.: 1) ICISS uznaje, że R2P przechodzi z państwa na społeczność międzynarodową wówczas, gdy państwo nie potrafi lub też nie chce (unable or unwilling) chronić własnych obywateli, z kolei w dokumencie z 2005 r. ograniczono się do sytuacji, gdy państwo ewidentnie zawodzi (manifestly failing); 2) ICISS zakłada, że interwencja humanitarna może mieć miejsce w sytuacji wystąpienia poważnej i nieodwracalnej szkody dla jednostek lub też wysokiego prawdopodobieństwa pojawienia się takiej szkody, włączając zabijanie lub czystki etniczne na dużą skalę, podczas gdy dokument z 2005 r. ogranicza się do czterech przypadków: ludobójstwa, zbrodni wojennych, czystek etnicznych oraz zbrodni przeciwko ludzkości; 3) ICISS uznaje, że społeczność międzynarodowa jest odpowiedzialna za podjęcie działań, podczas gdy dokument z 2005 r. stanowi, że społeczność międzynarodowa winna jedynie być przygotowana na podjęcie działań w każdym 
Koncepcja R2P wyeksponowana w dokumencie końcowym szczytu z 2005 r. znalazła następnie potwierdzenie w rezolucjach NZ. W 2009 r. sekretarz generalny NZ wskazał trzy filary niezbędne do implementowania R2P: odpowiedzialność państwa za ochronę, międzynarodową pomoc i budowanie potencjału, terminową i stanowczą odpowiedź mającą na celu zapobieżenie ludobójstwu, czystkom etnicznym, zbrodniom wojennym oraz zbrodniom przeciwko ludzkości i powstrzymanie ich [The Responsibility... 2015, Implementing the Responsibility... 2009, Responsibility to Protect... 2012]. W 2013 r. zobowiązanie do ochrony ludności przed aktami ludobójstwa, zbrodniami wojennymi, czystkami etnicznymi oraz zbrodniami przeciwko ludzkości zostało potwierdzone przez RB [Statement by the President of the Security Council... 2013, s. 3]. W 2016 r. RB jednomyślnie przyjęła natomiast rezolucję odnoszącą się do opieki zdrowotnej w konflikcie zbrojnym, w której wzywa do lepszej ochrony zdrowotnej, stwierdzając, że celowe ataki na szpitale i personel medyczny stanowią zbrodnie wojenne. Rada raz jeszcze potwierdziła, że państwa ponoszą główną odpowiedzialność za ochronę własnej ludności oraz podkreśliła szczególne znaczenie odpowiedzialności za akty naruszenia międzynarodowego prawa humanitarnego [Resolution 2286... 2016]. Dodać należy, że jest to pierwsza rezolucja RB dotycząca opieki zdrowotnej w konflikcie zbrojnym i 46 rezolucja przywołująca odpowiedzialność państwa za ochronę osób cywilnych przed zbrodniami ludobójstwa, zbrodniami wojennymi, zbrodniami przeciwko ludzkości oraz czystkami etnicznymi.

Koncepcja R2P przywołana została w rezolucji z 1973 r., będącej reakcją na sytuację w Libii. Państwa członkowskie, działając same lub przez organizacje regionalne, zostały upoważnione do podjęcia wszelkich niezbędnych środków w celu ochrony ludności cywilnej oraz zaludnionych obszarów zagrożonych atakiem, z wykluczeniem obcych sił okupacyjnych w jakiejkolwiek formie i na jakiejkolwiek części terytorium Libii [Resolution 1973... 2011, s. 3]. R2P została również przywołana przez RB w związku z sytuacją w Demokratycznej Republice Konga. W preambule czytamy, że na rządzie Demokratycznej Republiki Konga spoczywa podstawowa odpowiedzialność za zapewnienie bezpieczeństwa na własnym terytorium oraz za ochronę osób cywilnych przy poszanowaniu rządów prawa, praw człowieka i międzynarodowego prawa humanitarnego [Resolution 1991... 2011]. Natomiast po raz pierwszy odwołanie do koncepcji R2P znalazło

indywidualnym przypadku; 4) ICISS uważa interwencję bez zgody RB za dopuszczalną, podczas gdy dokument z 2005 r. wymaga, by o każdym użyciu środków przymusu decydowała RB. Dodać należy, że rozdział VII Karty NZ nie wspomina o interwencji humanitarnej, to Rada rozszerzyła interpretację rozdziału VII, tak by objąć wewnątrzpaństwowe kryzysy humanitarne, co znalazło odzwierciedlenie w rezolucji 688 z $1991 \mathrm{r}$. 
się w rezolucji 1674 Rady Bezpieczeństwa, dotyczącej ochrony ludności cywilnej w konfliktach zbrojnych [Resolution $1674 \ldots$... 2006, s. 2].

Mimo że koncepcje R2P będące wynikiem prac komisji ICISS oraz prac szczytu NZ z 2005 r. wyraźnie się od siebie różnią, nawiązują do wspólnego dziedzictwa, ponieważ stanowią przejaw myślenia w duchu postwestfalskim, politycznego liberalizmu oraz humanitarnego solidaryzmu [Newman 2013, s. 240].

Należy wspomnieć, że obecnie wyłania się nieco inna koncepcja, a mianowicie odpowiedzialność w trakcie ochrony (responsibility while protecting - RwP). W koncepcji tej kładzie się nacisk na większą ostrożność i rozwagę ze strony społeczności międzynarodowej podejmującej działania w ramach R2P. Sprowadza się to do stosowania zestawu kryteriów w odniesieniu do interwencji militarnej obejmujących: odpowiedzialność, ocenę i zapobieganie [Österdahl 2013, s. 459-486; Gözen Ercan 2016] ${ }^{4}$. W koncepcji RwP uznaje się zapobieganie za najlepszą politykę, a użycie sił zbrojnych za ostateczny środek, który zawsze winien uzyskać sankcję Rady Bezpieczeństwa w ramach rozdziału VII Karty NZ lub w wyjątkowych sytuacjach Zgromadzenia Ogólnego w ramach rezolucji „Zjednoczeni dla pokoju” (Uniting for Peace). Ponadto użyciu sił zbrojnych zawsze winno towarzyszyć kierowanie się zasadą proporcjonalności i nie powinno ono wykraczać poza mandat przyznany przez RB lub ZO ani też powodować więcej szkód niż te, którym miało zapobiec [Letter dated 9 November 2011 from the Permanent Representative of Brazil... 2011]. Koncepcja RwP uznająca zapobieganie za najlepszą politykę oraz wzywająca do regularnego monitorowania i dokonywania okresowej oceny użycia sił zbrojnych, tak by minimalizować ich wpływ na osoby cywilne, jest postrzegana jako uzupełnienie R2P - dodatkowa odpowiedzialność i wytyczne dotyczące monitorowania implementowania użycia środków militarnych.

\section{Odpowiedzialność za ochronę a etyka międzynarodowa}

Należy przede wszystkim zwrócić uwagę, że co do zasady zabroniona jest interwencja w wewnętrzne sprawy państw, tj. sprawy pozostające pod jurysdykcją krajową, natomiast do wyjątków należy możliwość przeprowadzenia interwencji na podstawie postanowienia rozdziału VII Karty NZ, które stanowi, że RB stwierdza istnienie zagrożenia lub naruszenia pokoju bądź aktu agresji oraz udziela zaleceń lub decyduje, jakie środki należy zastosować w celu utrzymania lub przywrócenia międzynarodowego pokoju lub bezpieczeństwa [Karta Narodów

${ }^{4}$ Więcej nt. brazylijskiej inicjatywy odpowiedzialności w czasie ochrony oraz chińskiej propozycji odpowiedzialnej ochrony (responsible protection - RP) zob. [Grzebyk 2015, s. 74-75]. 
Zjednoczonych... 1945, art. 39]. Należy też zauważyć, że przemoc krajowa (zbrodnie objęte R2P, takie jak: ludobójstwo, zbrodnie wojenne, czystki etniczne oraz zbrodnie przeciwko ludzkości) nie jest uznawana per definitione za zagrożenie międzynarodowe [Doyle 2011, s. 73]. Niezależnie od tego zbrodnie ludobójstwa są zakazane przez wiążące prawo międzynarodowe - Konwencję w sprawie zapobiegania i karania zbrodni ludobójstwa [1948], która w artykule pierwszym stanowi, że wysokie umawiające się strony potwierdzają, że ludobójstwo popełnione zarówno w czasie pokoju, jak i podczas wojny stanowi zbrodnię w obliczu prawa międzynarodowego oraz zobowiązują się zapobiegać tej zbrodni i ją karać.

R2P ma kluczowe znaczenie z punktu widzenia zasad etycznych odnoszących się zarówno do nieinterwencji, jak i do interwencji - ingerencji w polityczną niezależność i integralność terytorialną suwerennego państwa. Były one usprawiedliwiane przez uczonych, polityków, ale też przez zwykłych obywateli, przy czym każdy poszukiwał dobrych etycznych powodów, dla których z jednej strony należy stosować się do zasad nieinterwencji, z drugiej zaś w niektórych sytuacjach je zignorować [Doyle 2011, s. 74].

R2P stanowi przede wszystkim odpowiedź na interwencje w przypadku konfliktów etnicznych, które miały miejsce w byłej Jugosławii i w Timorze Wschodnim w połowie i pod koniec lat 90. ubiegłego wieku, a także po $2000 \mathrm{r}$. Jest to również odpowiedź na niechęć społeczności międzynarodowej do powstrzymania ludobójstwa w Rwandzie w 1994 r., a także na niemożność niezwłocznego zaangażowania się aktorów międzynarodowych w następstwie tego zdarzenia [Leveringhaus 2014, s. 165; Zajadło-Węglarz 2015, s. 199]. Pomimo formalnego zobowiązania do ochrony niejednokrotnie mieliśmy do czynienia z głosami sprzeciwu ze strony państw na forum RB oraz Rady Praw Człowieka NZ odnośnie do sytuacji w Darfurze, Birmie, Libii, na Wybrzeżu Kości Słoniowej, obecnie zaś w Syrii [Quinton-Brown 2013, s. 263; Holmes 2014, s. 126-145; Cairns 2014, s. 146-161; Doyle 2016, s. 14-31].

R2P mimo wszystkich swoich słabości właściwych dla całej dziedziny prawa międzynarodowego zasługuje na szczególną uwagę ze względu na bezpośrednie inspiracje zasadami etyki odpowiedzialności. Przybliża ideę międzynarodowego ładu moralnego, którego kształtowanie się należy uznać za jedno z ważniejszych osiągnięć ludzkości, a zwłaszcza społeczności międzynarodowej. W świecie targanym konfliktami i poddawanym grze egoizmów stanowi rodzaj myślenia wybiegającego w przyszłość, nie pozwala bowiem zapomnieć, że rodzaj ludzki określa nie tylko „mieć”, lecz przede wszystkim „być”. Inną wartością myślenia w kategoriach etycznych jest ustawiczne kwestionowane przyjętych standardów w imię bezpieczeństwa, solidarności, godności ludzkiej i dobrobytu. 


\section{Uwagi końcowe}

Szczyt NZ w Nowym Jorku w 2005 r. był w pewnym sensie przełomowy, a dokument końcowy zyskał jednomyślne poparcie państw członkowskich. Paragrafy 138-139 jeszcze bardziej zawęziły elementy wydzielające R2P z międzynarodowych praw człowieka lub zabijania na dużą skalę do czterech szczególnych przypadków: ludobójstwa, zbrodni wojennych, czystek etnicznych oraz zbrodni przeciwko ludzkości. Ograniczona została też władza upoważniająca do zastosowania środków przymusu do RB w zgodzie z postanowieniami Karty NZ, w tym rozdziału VII, w odniesieniu do każdego indywidualnego przypadku ma więc charakter uznaniowy [Doyle 2011, s. 80].

Co do zasady R2P nie może pretendować do rangi normy prawa międzynarodowego, ale po szczycie w 2005 r. można domagać się jego legitymizacji, co z kolei ma implikacje dla etyki międzynarodowej. Realiści będą musieli uznać, że R2P staje się częścią tego, co stanowi zwyczajowy standard zachowania stabilizacyjnego - standard reputacji, który winien być pominięty tylko wówczas, jeśli wchodzą w grę istotne interesy bezpieczeństwa. Z kolei neomarksiści, kwestionujący granice w imię solidarności klasowej, będą również musieli uznać, że istnieje nowa płaszczyzna i standard polityki krajowej [Doyle 2011, s. 83].

Koncepcja R2P, która co do zasady stoi w sprzeczności z zasadą suwerenności, wpływa na zmianę jej rozumienia. Suwerenność jest tutaj rozumiana jako pozytywne zobowiązanie państw do ochrony własnych obywateli (i nie tylko); jest to zobowiązanie państw do ochrony przed zagrożeniem zarówno zewnętrznym, jak i wewnętrznym, w czasie wojny i w czasie pokoju, zobowiązanie do ochrony przed naruszeniami praw człowieka, jak również do troszczenia się o możliwości rozwoju i dobrobyt. Suwerenne państwo staje się więc aktywnym uczestnikiem życia politycznego, gospodarczego i społecznego.

Analizę etyczną, oznaczającą zastosowanie zasad moralnych w celu określenia właściwego kierunku działań, można zastosować w przypadku moralnych konfliktów (wyborów) pomiędzy suwerennością a interwencją, porządkiem a sprawiedliwością, kosmopolitaryzmem a komunitaryzmem. Natomiast w świecie, w którym zagrożenia bezpieczeństwa przyjmują wymiar globalny, popieranie R2P staje się racjonalnym, a zarazem etycznym wyborem.

\section{Literatura}

2005 World Summit Outcome [2005], Resolution adopted by the General Assembly on 16 September 2005, United Nations, General Assembly, A/RES/60/1.

Baaz M. [2013], Beyond Order versus Justice: Middle-Ground Ethics and the Responsibility to Protect [w:] Ethical Reasoning in International Affairs. Arguments from the Middle Ground, ed. C. Navari, Palgrave Macmillan, New York. 
Cairns E. [2014], R2P and Humanitarian Action, „Global Responsibility to Protect”, vol. 6, nr 2, https://doi.org/10.1163/1875984X-00602004.

Constitutive Act of the African Union [2000], http://www.au.int/en/about/constitutive_act (data dostępu: 30.11.2016).

Doyle M.W. [2011], International Ethics and the Responsibility to Protect, „International Studies Review", vol. 13, nr 1, https://doi.org/10.1111/j.1468-2486.2010.00999.x.

Doyle M.W. [2016], The Politics of Global Humanitarianism: The Responsibility to Protect before and after Libya, ,International Politics”, vol. 53, nr 1, https://doi.org/ 10.1057/ip.2015.35.

Frost M. [2013], Middle-Ground Ethics and Human Rights in International Relations [w:] Ethical Reasoning in International Affairs. Arguments from the Middle Ground, ed. C. Navari, Palgrave Macmillan, New York.

Gözen Ercan P. [2016], Debating the Future of the 'Responsibility to Protect': The Evolution of a Moral Norm, Palgrave Macmillan, London.

Grzebyk P. [2015], Miejsce interwencji zbrojnej w koncepcji „odpowiedzialność za ochronę” $(R 2 P)$, ,Stosunki Międzynarodowe”, nr 3.

Halpern M. [1964], The Morality and Politics of Intervention [w:] International Aspects of Civil Strife, ed. J.N. Rosenau, Princeton University Press, Princeton.

Hehir A. [2013], The Responsibility to Protect as the Apotheosis of Liberal Teleology [w:] Libya, the Responsibility to Protect and the Future of Humanitarian Intervention, eds A. Hehir, R. Murray, Palgrave Macmillan, New York.

Heinze E.A., Steele B.J. [2013], The (D)evolution of a Norm: R2P, the Bosnia Generation and Humanitarian Intervention in Libya [w:] Libya, the Responsibility to Protect and the Future of Humanitarian Intervention, eds A. Hehir, R. Murray, Palgrave Macmillan, New York.

Holmes J. [2014], Responsibility to Protect. A Humanitarian Overview, ,Global Responsibility to Protect", vol. 6, nr 2, https://doi.org/10.1163/1875984x-00602003.

Hutchings K. [2001], International Politics and Ethical Life [w:] Ethics and International Relations, eds H. Seckinelgin, H. Shinoda, Palgrave Macmillan, New York.

Implementing the Responsibility to Protect [2009], Report of the Secretary-General, United Nations, General Assembly, A/63/677, 12 January.

Karta Narodów Zjednoczonych, Statut Międzynarodowego Trybunału Sprawiedliwości i Porozumienie ustanawiające Komisję Przygotowawczą Narodów Zjednoczonych [1945], Dz.U. 1947 nr 23 poz. 90.

Knight W.A. [2011], The Development of the Responsibility to Protect - From Evolving Norm to Practice, „Global Responsibility to Protect”, vol. 3, nr 1, https://doi.org/ 10.1163/187598411x549468.

Konwencja w sprawie zapobiegania i karania zbrodni ludobójstwa [1948], Nowy Jork, 9 grudnia, Dz.U. 1952 nr 9 poz. 9 i nr 31 poz. 213.

Kuźniar R. [2015], Karski, Lemkin i odpowiedzialność za ochronę [w:] Jan Karski a odpowiedzialność za ochronę, eds E. Smolar, B.M.J. Szewczyk, Semper, Warszawa.

Letter dated 9 November 2011 from the Permanent Representative of Brazil to the United Nations addressed to the Secretary-General, General Assembly, Security Council, United Nations, A/66/551-S/2011/701.

Leveringhaus A. [2014], Liberal Interventionism, Humanitarian Ethics, and the Responsibility to Protect, ,Global Responsibility to Protect”, vol. 6, nr 2, https://doi.org/ $10.1163 / 1875984 x-00602005$. 
Max Planck Encyclopedia of Public International Law [2010], ed. R. Wolfrum, www. mpepil.com (data dostępu: 30.11.2016).

Mill J.S. [1859], A Few Words on Non-intervention, http://oll.libertyfund.org/titles/mill-the-collected-works-of-john-stuart-mill-volume-xxi-essays-on-equality-law-andeducation\#lf0223-21_head_040 (data dostępu: 30.11.2016).

A More Secure World: Our Shared Responsibility [2004], Report of the Secretary-General's High-level Panel on Threats, Challenges and Change, United Nations, General Assembly, A/59/565 29, 29 November.

Newman E. [2013], R2P: Implications for World Order, „Global Responsibility to Protect", vol. 5, nr 3, https://doi.org/10.1163/1875984x-00503002.

Österdahl I. [2013], The Responsibility to Protect and the Responsibility While Protecting: Why Did Brazil Write a Letter to the UN?, ,Nordic Journal of International Law”, vol. 82, nr 4, https://doi.org/10.1163/15718107-08204001.

Quinton-Brown P. [2013], Mapping Dissent: The Responsibility to Protect and Its State Critics, „Global Responsibility to Protect”, vol. 5, nr 3, https://doi.org/10.1163/ $1875984 \mathrm{x}-00503003$.

Reinold T. [2013], Africa's Emerging Regional Security Culture and the Intervention in Libya [w:] Libya, the Responsibility to Protect and the Future of Humanitarian Intervention, eds A. Hehir, R. Murray, Palgrave Macmillan, New York.

Resolution 1674 [2006], United Nations, Security Council, S/RES/1674.

Resolution 1973 [2011], United Nations, Security Council, S/RES/1973.

Resolution 1991 [2011], United Nations, Security Council, S/RES/1991.

Resolution 2286 [2016], United Nations, Security Council, S/RES/2286.

The Responsibility to Protect [2001], Report of the International Commission on Intervention and State Sovereignty, International Development Research Centre, Ottawa.

The Responsibility to Protect and the Third Pillar. Legitimacy and Operationalization [2015], eds D. Fiott, J. Koops, Palgrave Macmillan, New York.

Responsibility to Protect: Timely and Decisive Response [2012], Report of the Secretary-General, United Nations, General Assembly, Security Council, A/66/874-S/2012/578, 25 July.

Rose S.J. [2014], Moving Forward with the Responsibility to Protect: Using Political Inertia to Protect Civilians, „Boston College International and Comparative Law Review”, vol. 37, nr 1.

Smith M.J. [1989], Ethics and Intervention, „Ethics and International Affairs”, vol. 3, nr 1, https://doi.org/10.1111/j.1747-7093.1989.tb00209.x.

Statement by the President of the Security Council [2013], United Nations, Security Council, S/PRST/2013/2, 12 February.

Symonides J. [2006], Przyjęcie zasady „odpowiedzialności za ochronę” w procesie reformowania Narodów Zjednoczonych [w:] Prawo międzynarodowe - problemy $i$ wyzwania. Ksiega pamiattowa Profesor Renaty Sonnenfeld-Tomporek, red. J. Menkes, Elipsa, Warszawa.

Tukidydes [2003], Wojna peloponeska, Czytelnik, Warszawa.

VanLandingham R.E. [2012], Politics or Law? The Dual Nature of the Responsibility to Protect, „Denver Journal International Law and Policy”, vol. 41, nr 1.

Warner D. [2013], Are We Linguistically Left-Handed? In Search of Responsible, Ethical Subjects [w:] Ethical Reasoning in international Affairs. Arguments from the Middle Ground, ed. C. Navari, Palgrave Macmillan, New York. 
Zajadło J. [2005], Słuszna przyczyna jako przesłanka legitymizacyjna interwencji humanitarnej: studium z filozofii prawa międzynarodowego, „Kwartalnik Prawa Publicznego", nr 1/2.

Zajadło J. [2009], Koncepcja odpowiedzialności za ochronę (Responsibility to Protect) nowa filozofia prawa międzynarodowego? [w:] Świat współczesny wobec użycia siły. Dylematy prawa i polityki, red. J. Kranz, EuroPrawo, Warszawa.

Zajadło-Węglarz P. [2015], Odpowiedzialność państwa w koncepcji R2P [w:] Państwo $i$ terytorium $w$ prawie międzynarodowym, red. J. Menkes, E. Cała-Wacinkiewicz, Wydawnictwo C.H. Beck, Warszawa.

\section{International Ethics and Responsibility to Protect}

(Abstract)

The article examines a new institution of international law that has taken shape since the beginning of the 21st century: the responsibility to protect. This responsibility is interpreted in the light of theories of international relations and international ethics. In the article, analytical and descriptive research methods have been applied. While the relatively new institution of the responsibility to protect has, due to its importance, gained fairly widespread acceptance in the international community, it has also been criticised as too difficult to implement. Nevertheless, it deserves our attention as the most radical programme legitimising actions taken under the auspices of the United Nations to protect the civilian population when it is facing threat.

Keywords: ethics, responsibility, realism, liberalism, neo-Marxism, English school. 